\title{
Pengaruh Harga Terhadap Keputusan Pembelian I AM GEPREK BenSu Cabang Pekanbaru
}

\author{
RINA SUNDARI \\ Sekolah Tinggi Ilmu Ekonomi Riau \\ Jl. HR Subrantas KM 12 Panam Pekanbaru \\ E-mail: sundarina.rs@gmail.com
}

\begin{abstract}
This research was conducted to find out how far the price effect on the purchase decision of I AM GEPREK BenSu Pekanbaru branch. Respondents in this study amounted to 98 people consisting of students and lecturers of STIE Riau pekanbaru. Data processing is done using SEM WarpPLS. The results obtained are the price has a significant influence on purchasing decisions. The amount of influence is equal to 0.48 or $48 \%$ in building student loyalty. The remaining $52 \%$ is influenced by other factors.
\end{abstract}

Keywords: Price and Purchase Decision

Industri rumah makan atau tempat-tempat wisata kuliner menjadi sangat berkembang dan juga menjadi bagian keunikan tersendiri dalam dunia pariwisata. Istilah wisata kuliner menjadi sebuah gambaran akan arti pentingnya dunia kuliner, mencicipi berbagai keunikan kuliner akan menambah cita rasa individu dan juga menjadikan perbendaharaan rasa yang istimewa. Pemerintah membuat kebijakan khususnya yang dikeluarkan oleh Menteri Pariwisata No KM.73/PW.105/MPPT-85 yang menekankan bahwa setiap fasilitas kuliner seperti juga rumah makan dan restoran perlu menyediakan hidangan yang istimewa dan unik guna meningkatkan daya tarik wisatawan untuk menikmatinya. Dengan demikian para pengusaha harus memikirkan strategi penjualan yang sesuai dengan selera dan minat konsumen mengingat persaingan yang sangat ketat tadi di Pekanbaru.

Fenomena cita rasa makanan pedas masih terus bermunculan dan mewarnai industri kuliner Indonesia, terutama dipekanbaru. Besarnya peminat makanan pedas tentu sangat menggiurkan bagi pelaku bisnis. Sebut saja salah satunya, ayam geprek yang kini kian popular. Melihat adanya peluang dan tidak mau kehilangan momen, Ruben Onsu, pemeran dan pembawa acara televisi Indonesia, pun mendirikan restoran ayam geprek yang diberi nama I Am Geprek Bensu. Soal pedas, jangan ditanya. Pedas yang nagih ini berhasil membuat pelanggan terus menerus kembali untuk mencicipi nikmatnya ayam geprek dengan tingkat kepedasan 1 hingga 10.

Melihat ada banyaknya pebisnis yang membuka usaha dengan jenis serupa, sangatlah penting bagi Ruben untuk melakukan inovasi. Oleh karenanya, I Am Geprek Bensu pun menjadi pelopor ayam geprek pedas dalam balutan keju mozzarella dengan harga yang sangat terjangkau. Antusiasme pelanggan terhadap I Am Geprek Bensu ini pun tidak dapat terbendung. Antrian makanan baik dari pelanggan maupun pesanan melalui aplikasi online terus merajalela. Kini cabang Geprek Bensu pun sudah mencapai 15, hanya dalam waktu hitungan bulan. Bukan hanya terpusat di Jabodetakbek, gerai Geprek Bensu juga dapat ditemukan di Surabaya, Bandung, Malang, Solo, Palu, Lombok, Yogyakarta, Pontianak, Lampung, Jambi, Pekanbaru, Padang, Medan dan Palembang.

Dengan banyaknya gerai yang sudah ada pun, inovasi manajemen Geprek Bensu tidak hanya berhenti disana. Manajemen Geprek Bensu sangat mengedepankan pelayanan bagi para pelanggan. Salah satunya adalah dalam hal kecepatan pelayanan. Dalam hal ini, 
Geprek Bensu terbantu dengan penggunaan aplikasi kasir online Pawoon, yang mengedepankan kemudahan dalam proses input data penjualan yang mudah dan sangat praktis. Oleh karenanya, pelanggan tidak perlu menunggu dengan waktu yang lama karena proses transaksi pembayaran dapat dilakukan oleh kasir dengan cepat.

Teori pemasaran yang dipakai pertama menurut Kotler yang dikutip oleh Suyanto (2007) bahwa sebuah konsep pemasaran lebih kepada bagaimana seorang manajer sebagai upaya melaksanakan kegiatan manajerial memperkenalkan produk kepada konsumen agar konsumen tertarik membeli produk yang ditawarkan tersebut. Kemudian juga dijelaskan oleh Kotler dan Armstrong (2010) pemasaran menjadi sebuahusaha nyata dalam mana seorang dapat menciptakan nilai dan konusmen dapat merasa puas dari nilai yang ditawarkan dan dalam rangka menikmatinya. sehingga konsumen loyal merupakan inti pemikiran pemasaran. Selanjutnya dijelaskan oleh Rangkuti (2006) bahwa dengan berkembang dan tumbuhnya persaingan, maka perlu adanya strategi yang tepat dalam rangka memenangkan persaingan pasar tersebut yakni melalui strategi pemasaran yang menerapkan konsep 5P. Dengan demikian faktor bauran pemasaran jadi hal utama terutama harga yang dibahas dalam penelitian ini.

Tinjauan Pustaka mengenai Harga (Price) pertama menurut Kotler (2009) berkaitan dengan masalah harga sebuah produk, dapat dinyatakan bahwa harga menjadi sebuah sesuatu yang dalam bentuk sejumlah uang dan uang tersebut dibayarkan oleh konsumen kepada penyedia produk atau jasa dan nantinya ditukarkan dengan nilai yang ada. Kemudian juga ditegaskan oleh (Harjanto, 2009) bahwa harga sesuatu yang semestinya harus dibebankan kepada konsumen untuk dapat menikmati sebuah produk atau jasa yang disediakan oleh produsennya. Jadi harga merupakan ukuran untuk melakukan transaksi jual beli melalui alat tukar uang.

Tinjauan pustaka yang kedua Menurut Kotler dan Keller (2012:405), pengertian harga "price is not just a number on a tag. It comes in many forms and performs many functions. Rent, tuition, fares, fees, tolls, retainers, wages and commission are all the price you pay for some goods or services". Artinya harga bukan hanya angka dalam table tetapi Harga juga dapat berupa berbagai bentuk yang memiliki banyak fungsi seperti sewa, harga, biaya, pajak, gaji, upah dan komisi adalah semua harga yang dibayar untukmemperoleh barang dan jasa.

Menurut Peter Donnely (2010:43), the price of product and service often influence whether consumers will purchase them all at all and, if so, which competitive offering is selected. Artinya harga produk dan jasa sangat mempengaruhi konsumen dalam pembelian, dengan demikian penawar kompetitif dalam membeli barang dan jasa.

Menurut Buchari Alma $(2007 ; 169)$ harga adalah nilai suatu barang yang dinyatakan dengan uang.

Menurut Tjiptono menyebutkan harga adalah satuan moneter atau ukuran lainnya (termasuk barang dan jasa) yang ditukarkan agar memperoleh hak kepemilikan atau penggunaan suatu barang atau jasa.

Harga dikatakan mahal, murah atau biasa-biasa saja dari setiap individu tidaklah harus sama, karena tergantung dari persepsi individu yang dilatarbelakangi oleh lingkungan kehidupan dan kondisi individu (Schifman dan Kanuk, 2001 :105)

Dari berbagai defenisi menurut para ahli diatas, dapat disimpulkan yaitu penetapan suatu harga merupakan ukuran untuk memperoleh barang atau jasa dimana terkandung nilai intrinsic dan ekstrinsik yang berlaku untuk suatu waktu tertentu.

p.ISSN: 2407-800X e.ISSN: 2541-4356 
Menurut Djaslim Saladin (2007) terdapat beberapa tujuan yang dilakukan oleh seorang manajer dalam rangka menetapkan harga pada sebuah produk, diantaranya berkaitan dengan usaha untuk memaksimumkan keuntungan dan juga berkaitan dengan dengan adanya persaingan harga dapat digunakan untuk merebut pangsa pasar dan juga usaha untuk bagaimana pasar terkonsentrasi pada produk yang ditawarkan atau memerah pasar. Selain itu juga tujuan penetapan harga pada sebuah produk ini adalah untuk mendapatkan laba secara maksimal dan juga perlakuan terhadap sasaran tertentu dan juga dalam rangka kegiatan promosi perusahaan.

Indikator harga menurut Rinaldi Busman (2009), yaitu :

a. Kesesuaian harga dengan manfaat
produk
b. Kesesuaian harga dengan
pendapatan atau uang saku yang
diterima
c. Kesesuaian harga dengan kualitas
produk
Kemudian dapat juga dijelaskan oleh Philip Kotler (2012) bahwa terdapat beberapa indikator yang mengukur penerapan harga apakah sudah tergolong bersaing atau belum, dinataranya: daftar harga dapat produk yang ada, dimana adaya usaha untuk menjelaskan pada produk dengan label yang lebih jelas dan adanya kepastian. Kemudian penerapan diskon pada harga dengan menetapkan label diskon yang jelas, sehingga konsumen merasa lebih nyaman dalam mengeluarkan uangnyan. Kemudian adanya diskon yang diberikan secara tunai kepada pelanggan dalam memberikan berbagai kemudahan dan juga dikon dalam bentuk jumlah dan fungsional serta dalam bentuk musiman. Selain itu juga indikator ketiga adalah pembayaran yang dilakukan dalam bentuk kredit yang mana hal ini dapat membentu konsumen dalam mendapatkan produk dengan kemampuan terbatas dan juga diberikannya priode cicilan yang disesuaikan degan kemampuan pembeli.
Sebagaimana dijelaskan oleh Kasmir (2003) bahwa periode pembayaran dibagi kedalam 3 (tiga) bagian, yaitu : jangka pendek, jangka menengah dan jangka panjang. Jangka waktu kredit ini disesuaikan dengan jenis barang yang dibeli konsumen

Selain itu juga Zeithaml (1998) juga memberikan beberapa referensi indikator dalam menentukan harga antara lain harga yang diberikan dengan wajar dan juga adanya perkiraan harga yang memang sesuai dengan kemampuan konsumen dan juga penetapan harga berdasarkan pengorbanan.

Dari berbagai indikator harga menurut para ahli diatas, penulis memilih indicator harga menurut Rinaldi Busman (2009) dikarenakan indicator tersebut sesuai dengan produk yang akan diteliti.

Pengambilan keputusan oleh konsumen didasarkan pada persepsi suka atau tidak suka termasuk bermanfaat atau tidak barang yang akan dibelinya. Keputusan pembelian atau purchase decission menurut Kolter (2002: 204) adalah suatu tindakan konsumen untuk membentuk referensi diantara merekmerek dalam kelompok pilihan dan membeli produk yang paling disukai".

Menurut Alma (2013) bahwa keputusan pembelian adalah usaha yang dilakukan dengan melakukan berbagai pertimbangan yang matang guna mendapatkan produk yang diinginkan konsumen. Pertimbangan yang dilakukan menyangkut berbagai pertimbangan produk, juga merek dan kualitas serta model dan harga. Juga diikuti dengan cara pembayaran dan lain sebagainya. Keputusan pembelian juga dilakukan sampai pada saat pembelian dilakukan dan akan dengan mudah merubah konsumen untuk memilih produk atau jasa yang ditawarkan.

Menurut Marimin dan Nurul Maghfiroh (2010) mengambil atau membuat keputusan adalah suatu proses yang dilaksanakan seseorang berdasarkan 
pengetahuan dan informasi yang ada dengan harapan sesuatu akan terjadi.

Selain itu juga Fandy Tjiptono (2002) menerangkan terkadang keputusan menjadi hal unik dari konsumen, dimana pertimbangan konsumen dalam memilih produk menjadi masa depan dari perusahaan dalam keberlanjutan bisnis yang dijalankan. Sedangkan Kotler (2003) menjelaskan bahwa keputusan konsumen menjadi hal nyata yang dilakukan konsumen dalam memilih sebuah barang atau jasa yang akan dikonsumsikannya.

Proses keputusan pembelian bukan hanya sekedar mengetahui sejauhmana factor-faktor yang akan mempengaruhi konsumen dalam membeli, tetapi juga merupakan tahap-tahap konsumen dalam mengambil keputusan sebelum terjadinya pembelian. Menurut Simamora (2004 :15), terdapat 5 peran yang terjadi dalam keputusan pembelian

1. Pemrakarsa :adalah orang yang pertama kali menyarankan atau memberi ide kepada konsumen untuk membeli barang atau jasa.

2. Pemberi pengaruh : adalah orang yang pandangan/nasehatnya dapat memberi pengaruh melalui gaya komunikasi persuasif dalam pengambilan keputusan akhir bagi konsumen

3. Pengambil keputusan : adalah orang atau konsumen yang menjadi target bagi perusahaan karena konsumen ini dapat menentukan sebagian atau keseluruhan keputusan pembelian, apakah pembeli, apa dibeli, kapan mau membeli, bagaimana cara membeli, dan dimana akan dibeli.

4. Pembeli : orang yang melakukan pembelian secara nyata

5. Pemakai : orang yang mengkomsumsi atau menghabiskan nilai guna barang dan jasa.

Berdasarkan uraian dan juga penjelasan yang ada di atas, maka dapat dengan jelas disimpulkan bahwa sebuah keputusan pembelian yang diambil adalah keputusan akhir yang merupakan pemecahan masalah kebutuhannya.

Menurut Kotler (2003) bahwa terdapat lima tahapan seorang konsumen dalam melakukan proses pengambilan keputusan pembelian antara lain dengan tahap pertama berkaitan dengan usaha pengenalan masalah dan juga dilanjutkan dengan mencari informasi serta melakukan evaluasi terhadap informasi yang ada dengan memberikan alternative keputusan dan juga melakukan pengambilan keputusan dalam pembelian dan menjadi sebuah perilaku pembelian.

Adapun penjelasan dari tahap keputusan pembelian tersebut yaitu sebagai berikut :

1. Pengenalan masalah, adalah tahap pertama dimana konsumen menyadari bahwa ada masalah atau kesenjangan dari kebutuhan yang nyata dan yang di inginkan

2. Pencarian informasi, ialah pada tahap ini konsumen sudah mencari tahu informasi dari barang dan jasa yang dibutuhkan. Pencarian informasi ini bisa dari orang terdekat, keluarga dan social media lainnya

3. Evaluasi alternatif, adalah konsumen sudah mendapatkan beberapa alternative untuk mendapatkan kebutuhan yang di inginkan dan mengevaluasi beberapa alternative keputusan tersebut.

4. Keputusan pembelian, adalah pada tahap ini konsumen sudah mengambil keputusan, barang atau jasa apakah yang dibeli karena sudah mengevaluasi beberapa alternative kemungkinan tadi.

5. Perilaku pembelian, adalah pada tahap ini perusahaan sebaiknya mengetahui bagaimana perilaku konsumen sesudah melakukan pembelian, apakah puas atau tidak puas yang bertujuan untuk menciptakan konsumen yang loyal. 
Pendapat lebih lanjut berkaiatn dengan masalah tahapan konsumen dalam mengadopsi sebuah produk menurut Rogers dalam Kotler (2003) antara lan: adanya kesadaran dari calon pembeli untuk mempertimbangkan informasi produk, kemudian adanya minat konsumen terhadap produk yang ditawarkan dan juga melakukan evaluasi terhadap produk yang ditawarkan dan juga mencoba untuk menilai dan mempertimbangkan keputusan yang diambil dan juga menerima produk yang ditawarkan.

Pada minat, konsumen sebaiknya dirangsang untuk mencari informasi mengenai sebuah produk. Ada 4 Titik tolak konsumen untuk memahami citra produk yang dapat mempengaruhi perilaku pembelian konsumen yaitu :

\section{Perhatian (Attention) Timbulnya perhatian konsumen atau rasa tertarik konsumen terhadap suatu produk.}

2. Minat (Interest) Setelah Munculnya rasa tertarik, maka mulailah timbul hasrat dan keinginan untuk memiliki suatu produk atau barang dan jasa.

3. Keinginan (Desire) Setelah munculnya minat, maka mulailah timbul hasrat atau keinginan untuk memilih dan memiliki beberapa barang atau jasa tersebut.

4. Tindakan (Action) Pada proses ini konsumen sudah sampai pada tahap keputusan pembelian, setelah melewati beberapa fase sebelumnya

Keputusan pembelian harus tetap jadi perhatian para pemasar. Keputusan pembelian dapat terjadi bila perusahaan dapat terus berinovasi menciptakan produk yang sesuai dengan kebutuhan dan keinginan konsumen.

Menurut Morissan (2010) bahwa pasca keputusan pembelian seorag konsumen berniat melakukan pembelian secara teratur artinya perusahaan harus terus memotivasi konsumen biar terjadi pembelian yang nyata. Dan juga menurut Kotler dan Armstrong (2010) dengan memberikan berbagai pilihan kepada konsumen maka konsumen akan mendapatkan informasi pilihan yang pada akhirnya konsumen akan memilih dengan demikian tugas pemasar harus terus memberi stimulus agar konsumen melakukan keputusan pembelian.

\section{METODE}

Jenis penelitian yang digunakan adalah penelitian survey. Sumber daya primer dan skunder. Data primer diperoleh dari sampel yang berjumlah 98 orang yang terdiri dari mahasiswa/I dan dosen STIE RIAU pekanbaru, data dikumpulkan dengan menggunakan kuesioner online. Pengolahan data dilakukan dengan menggunakan alat analisis SEM WarpPLS

\section{HASIL}

Berdasarkan hasil penelitian kepada 98 orang mahasiswa dan Dosen STIE Riau berkaitan tentang pengaruh harga terhadap keputusan pembelian IAM Geprek BenSu cabang Pekanbaru dapat dilihat dari model berikut ini:

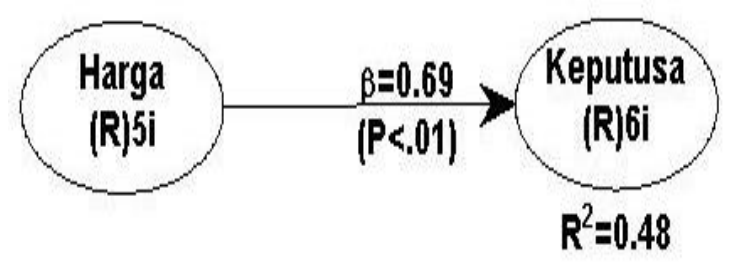

\section{Gambar 1: Pengaruh harga terhadap keputusan pembelian produk I AM Geprek BenSu}

Model di atas dapat dilihat bahwa harga mempunyai pengaruh yang signifikan terhadap keputusan pembelian. Besarnya nilai pengaruh yakni sebesar 0,48 atau $48 \%$ dalam membangun loyalitas mahasiswa. Sisanya sebesar $52 \%$ dipengaruhi oleh faktor lain.

Apabila dilihat dari indicator harga dapat diketahui bahwa jawaban dominan responden setuju dari pertanyaan produk IAM Geprek Bensu tergolong kategori harga terjangkau. Dengan harga yang terjangkau dapat menjangkau seluruh lapisan masyarakat untuk mampu membeli IAM Geprek Bensu 
1. Produk IAM GEPREK BenSu tergolong kategori harga terjangkau 97 tanggapan
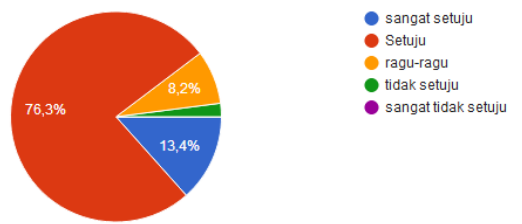

Dari diagram dibawah dapat dilihat dari indicator harga bahwa IAM Geprek Bensu menyediakan pilihan produk makanan dan minuman dengan berbagai harga, mayoritas jawaban responden setuju dengan berbagai variasi produk ayam geprek dengan berbagai harga

2. IAM GEPREK BenSu menyediakan pilihan produk makanan dan minuman dengan berbagai harga

98 tanggapan
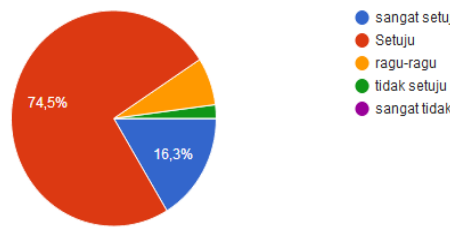

- Setuju

ragu-ragu

- sangat tidak setuju

Apabila dilihat dari sisi Kualitas Produk, mayoritas jawaban responden Setuju dengan indicator harga sesuai dengan kualitas produk yang disediakan.

Harga produk IAM GEPREK BenSu sesuai dengan kualitas produk yang disediakan

98 tanggapan
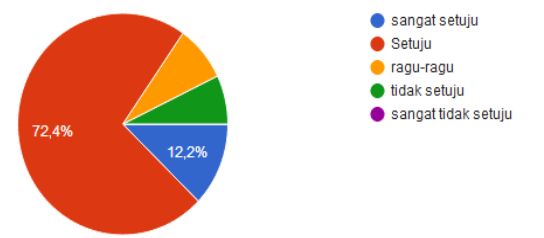

Dari diagram dibawah dapat dilihat bahwa mayoritas responden setuju dengan Harga produk IAM GEPREK BenSu sesuai dengan manfaat yang diperoleh. Artinya konsumen akan merasa puas setelah makan di IAM Geprek BenSu

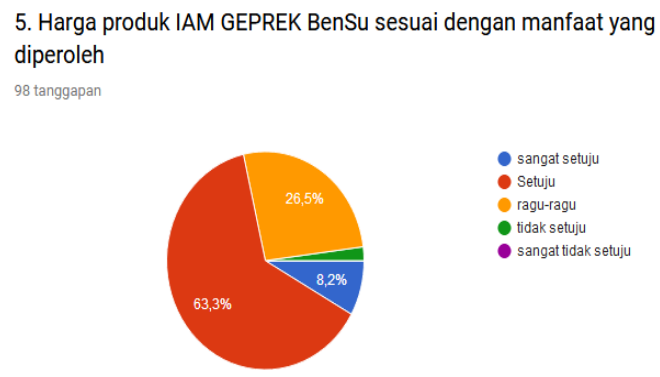

Dari diagram di bawah dapat pula dilihat jawaban responden mayoritas setuju sebanyak $64,3 \%$ dengan pernyataan saya memilih produk makanan dan minuman IAM Geprek BenSu karena sesuai dengan kebutuhan saya. Artinya harga produk IAM Geprek BenSu cocok dikantong sebagian besar mahasiswa.

6. Saya memilih produk makanan dan minuman IAM GEPREK BenSu karena sesuai dengan kebutuhan saya

98 tanggapan
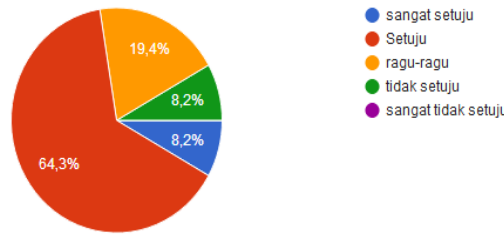

Apabila dilihat dari variable keputusan pembelian, pernyataan saya telah melakukan evaluasi terhadap produk makanan dan minuman IAM Geprek BenSu sebelum membeli, sebagian besar jawaban responden setuju sebanyak $56,3 \%$. Artinya dari beberapa produk ayam geprek, responden lebih memilih IAM Geprek BenSu untuk dikonsumsi.

7. Saya telah melakukan evaluasi terhadap produk makanan dan minuman IAM GEPREK BenSu sebelum membeli

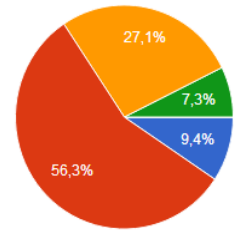

sangat setu - Setuju ragu-ragu - sangat tidak setuju

Dari diagram di bawah masih dapat kita lihat pernyataan dari variable keputusan pembelian yang menyatakan bahwa saya yakin bahwa saya sudah mengambil keputusan yang tepat saat membeli produk makanan dan minuman

p.ISSN: $2407-800 X \quad$ e.ISSN: 2541-4356 
IAM Geprek Bensu mayoritas jawaban responden setuju sebanyak $67,3 \%$, artinya setelah melakukan evaluasi dari beberapa tempat yang menjual ayam geprek, responden yakin untuk membeli IAM Geprek BenSu.

8. Saya yakin bahwa saya sudah mengambil keputusan yang tepat saat membeli produk makanan dan minuman IAM GEPREK BenSu 98 tanggapan
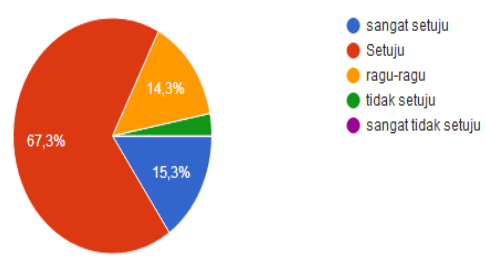

Pernyataan lain dari variable keputusan pembelian yang menyatakan bahwa saya merasa puas setelah membeli produk makanan dan minuman IAM Geprek Bensu, sebagian besar responden menjawab setuju 59,2\%. Artinya setelah melakukan pembelian dan mencoba rasa IAM Geprek BenSu responden merasa cocok dengan rasa ayam yang ditawarkan produk franchise ini. 9. Saya merasa puas setelah membeli produk makanan dan minuman IAM GEPREK BenSu
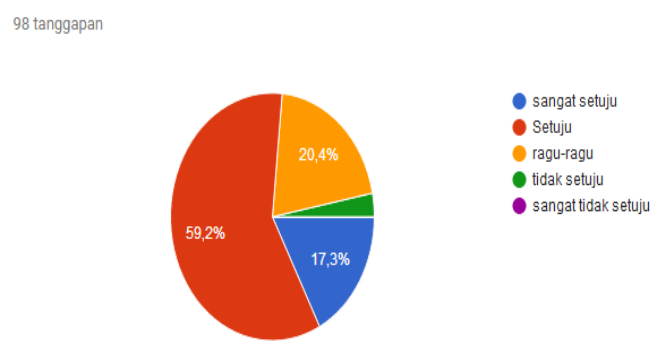

Dari pernyataan di bawah ini yang menyatakan bahwa saya akan merekomendasikan produk makanan dan minuman IAM Geprek Bensu pada teman saya, sebagian besar responden setuju sebesar $64,6 \%$. Hal ini menunjukkan bahwa setelah membeli,mencoba dan merasakan produk IAM Geprek BenSu Responden merasa puas dan senang sehingga mau untuk merekomendasikan produk ini kepada temantemannya.
10. Saya akan merekomendasikan produk makanan dan minuman IAM GEPREK BenSu pada teman saya

96 tanggapan

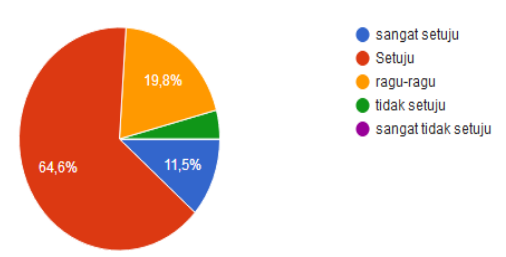

Dari pernyataan terakhir untuk variable keputusan pembelian yang menyatakan jika saya memiliki kesempatan, saya akan dating kembali untuk membeli produk IAM Geprek BenSu, mayoritas responden menjawab setuju sebesar 70,4\%. Hal ini menunjukkan gambaran bahwa sebagian besar responden merasa puas makan di IAM GEPREK BenSu sehingga jika responden mempunyai kesempatan, responden berminat untuk dating kembali mencicipi IAM GEPREK BenSu.

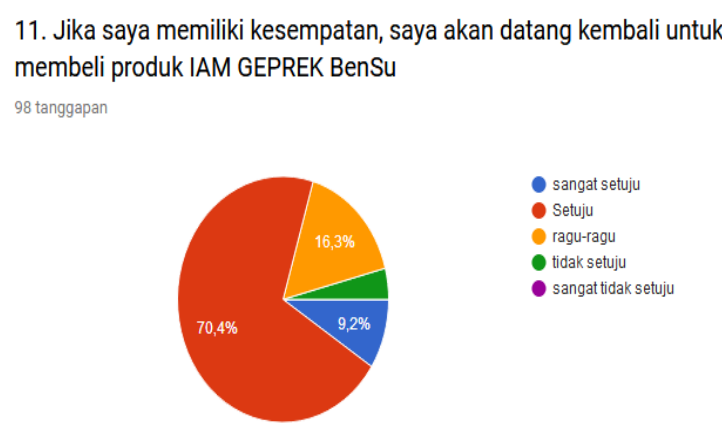

\section{PEMBAHASAN}

Hasil penelitian tersebut menunjukkan bahwa terbukti produk IAM GEPREK BenSu tergolong harga yang terjangkau, produk makanan dan minuman IAM GEPREK BenSu tersedia dengan berbagai harga dan harga produk IAM GEPREK BenSU sesuai dengan kualitas sehingga jika ada kesempatan responden bersedia untuk datang kembali membeli IAM GEPREK BenSu.

Hasil penelitian ini sejalan dengan apa yang dikatakan oleh Tambunan, K., \& Widiyanto, I. (2012) bahwa harga berpengaruh signifikan terhadap keputusan pembelian produk olahan makanan di Bandeng Presto Semarang. Juga ditegaskan Hadiyati, H. (2014) bahwa dalam menjual 
produk perlu memperhatikan harga, produk, lokasi dan juga promosi.

\section{SIMPULAN}

Dari pembahasan diatas dapat diambil kesimpulan bahwa produk IAM GEPREK BenSu tergolong harga yang terjangkau, produk makanan dan minuman IAM GEPREK BenSu tersedia dengan berbagai harga dan harga produk IAM GEPREK BenSU sesuai dengan kualitas sehingga jika ada kesempatan responden bersedia untuk datang kembali membeli IAM GEPREK BenSu.

\section{DAFTAR RUJUKAN}

A Tambunan, K., \& Widiyanto, I. (2012). Analisis Pengaruh Citra Merek, Persepsi Kualitas, Dan Harga Terhadap Keputusan Pembelian Bandeng Presto (Studi Kasus pada Konsumen di Bandeng Presto Semarang) (Doctoral dissertation, Fakultas Ekonomika dan Bisnis).

Alma, Buchari, 2007. Manajemen Pemasaran dan Pemasaran Jasa. Edisi revisi. Bandung Alfabeta

Armstrong dan Philip Kotler. 2003. Manajemen pemasaran, edisi kesembilan, Jakarta : PT. Indeks Gramedia

Djaslim Saladin, 2007, manajemen Pemasaran, bandung : Linda karya

Freddy, Rangkuti. 2006. Tekhnik mengukur dan strategi meningkatkan kepuasan pelanggan. Jakarta : Penerbit. PT. Gramedia Pustaka Utaman

Hadiyati, H. (2014). Analisis Penjualan Lemari Es Merek Lg Pada PT. Lg Electronics Indonesia Cabang Pekanbaru. Jurnal Ilmiah Ekonomi dan Bisnis Unilak, 11(2).
Harjanto, Rudy, 2009, Prinsip-prinsip Periklanan. Jakarta, PT. Gramedia Jakarta

Kotler dan keller, 2012. Manajemen Pemasaran. Edisi 12. Jakarta, Erlangga

Kotler, Philip \& Gary Armstrong, 2010. Prinsip-prinsip pemasaran. Jilid 1 dan 2 edisi keduabelas. Jakarta : Erlangga

Kotler, Philip \& Kevin K Lane, 2009. Manajemen Pemasaran. Jilid 1. Edisi ketigabelas. Jakarta : Erlangga

M. Morrisan, 2010. Periklanan Komunikasi Pemasaran terpadu, Jakarta : Penerbit Kencana

Parasuraman, V.A. Zeithaml and L.L. Berry, 1998, SERVQUAL : A Multiple item scale for meansuring consumer perception of service quality, hal 64 , jurnal of retailing

Peter, Donnelly, Jr, 2010. Marketing management knowled and skills, ninth edition, amerika serikat : McGraw-Hill

Schifman dan kanuk, 2001. Riset Perilaku Konsumen. PT. Gramedia Pustaka Utama, Jakarta

Simamora, Bilson, 2004. Panduan riset perilaku Konsumen. Jakarta : Gramedia

Suyanto, M.2007. Marketing Strategy Top Brand Indonesia. Yogyakarta: Andi Offset

Tjiptono, Fandy. 2010. Strategi pemasaran. Edisi 2, Andi Offset, Yogyakarta 